\title{
CEP 14-12
}

\section{Venture Capital Networks and Investment Performance in China}

\author{
Zhiyang Liu \\ Shanghai University of \\ Finance and Economics
}

Zhiqi Chen

Carleton University

September 2014

\section{CARLETON ECONOMIC PAPERS}
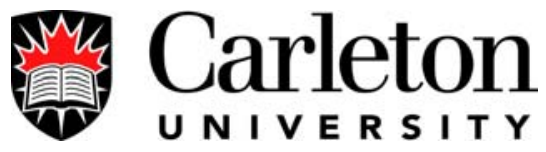

Department of Economics

1125 Colonel By Drive Ottawa, Ontario, Canada K1S 5B6 


\title{
VENTURE CAPITAL NETWORKS AND INVESTMENT PERFORMANCE IN CHINA*
}

\author{
Zhiyang Liu $^{\mathrm{a}}$ and Zhiqi Chen ${ }^{\mathrm{b}}$
}

September 2014

\begin{abstract}
We investigate the relationship between venture capital (VC) networks and investment performance in China. Distinct features of China's VC networks are captured in our econometric model through the inclusion of an index of network stability and a dummy variable that indicates a VC firm's connections with the Chinese state. Our econometric analysis shows that a VC firm's position in its network, its network stability and close connections with the state all contribute to its investment performance. Comparison with the findings in Hochberg et al. (2007) indicates that networks are more important for investment performance in China than in the US. Moreover, our analysis suggests that familiarity with local culture and customs and understanding of the idiosyncrasies of China's markets and institutions are important for the success of a VC firm in China.
\end{abstract}

Keywords: Venture capital; Networks; Investment performance; China

* The authors thank Wouter Stam, Bing-Huei Lin and the participants of the Babson College Entrepreneurship Research Conference Workshop (April 2012) for their comments on earlier versions of this paper. The authors also thank Guixing Wu and Dan Su Ming for their assistance in data collection and processing. Liu's research received financial assistance from the National Social Science Foundation of China..

a School of International Business Administration, Shanghai University of Finance and Economics, 777 Guo-ding Road, Shanghai 200433, China. E-mail addresses: zhiyang163@163.com; Tel: (86) 13524190123.

b Department of Economics, Carleton University, 1125 Colonel By Drive, Ottawa, Ontario, Canada K1S 5B6. E-mail addresses: zhiqi.chen@carleton.ca. Tel: (613)520-2600 extension 7456 


\section{INTRODUCTION}

Venture capital (VC) markets are characterized by strong relationships and networks (Hochberg et al. 2007). Instead of investing alone, VC firms tend to syndicate their investments with other VC firms (Lerner 1994). The literature has identified a number of reasons for investment syndication. The resource-based motive views syndication as a way for VC firms to pool resources such as experience, skills, contacts, and capital to better screen among investments and improve the chances of success of the selected deals (Bygrave 1988, Sahlman 1990, Lerner 1994, Brander et al. 2002, Kaplan and Stromberg 2004, Dimov and Milanov 2010, Hopp and Rieder 2011). Moreover, risk reduction and portfolio diversification are also seen as motives for syndicating investments (Bygrave 1988, Lerner 1994, Lockett and Wright 2001, Sorensen and Stuart 2001 and 2008, Stuart and Sorensen 2007). These motives for syndication imply that VC networks can potentially enhance the investment performance of VC firms. Indeed, a study of VC networks in the United States by Hochberg et al. (2007) finds that better-networked VC funds experience significantly better performance, and that the portfolio companies of better-networked VC firms are significantly more likely to survive to subsequent financing and eventual exit.

The objective of this paper is to examine the relationship between VC networks and investment performance in China. To the best of our knowledge, this is the first empirical study on the performance consequences of venture capital networks in China. There are two factors that make China a particularly interesting case to study this issue. First, after more than a decade of rapid growth, China now is the world's second largest market for venture capital 
investments. ${ }^{1}$ Its growing size, coupled with expectations of future economic growth, has made China a significant destination for venture capital investments by many international investors. It is then important to understand the role of VC networks in driving investment performance in China.

Second, compared with those in the United States, China's VC networks have some distinct features, specifically, the predominance of guanxi and the extensive intervention and involvement of the Chinese state in the economy. Guanxi, roughly translated as connections or relationships, "denotes the establishment of long-term reciprocal personal relationships that can create enduring trust” (McNally 2011 p2). The importance of guanxi in facilitating business dealings and collaborative ties among entrepreneurs in China has been well recognized (Park and Luo 2001, and McNally 2011). But does the predominance of guanxi in China’s VC markets magnify or reduce the impact of VC networks on investment performance? Furthermore, given the heavy and pervasive interventions of the Chinese state in the economy, the cultivation of guanxi with the agents and institutions of the state is particularly important (McNally 2011 p9). Thus, one would expect that the presence or absence of partnership with the agents or institutions of the Chinese state in a VC network would have an impact on investment performance.

For the most part, our econometric analysis follows the seminal work of Hochberg et al. (2007). In particular, we use three indices of centrality - degree, indegree, and outdegree - to measure the relative importance of each actor in VC networks. We adopt the "exit rate" -

\footnotetext{
${ }^{1}$ In 2010, the total amount of venture capital investments in China reached US $\$ 5.4$ billion, next only to the US with US\$23.3 billion in total investments.
} 
defined as the fraction of portfolio companies that are successfully exited via an initial public offering (IPO) or a sale to another company - as a proxy for investment performance.

To capture the distinct features of China's VC networks, we modify the econometric model of Hochberg et al. (2007) in two ways. First, we add an index of network stability to represent the role of guanxi that attaches great value to repeated relationships. Second, we include a dummy variable to investigate the performance implications of VC firms' connections with the Chinese state.

Our econometric analysis presents strong evidence that China's guanxi networks have a significant impact on the investment performance of VC firms. First, it shows that close connections with the state contribute to a VC firm's investment performance. The estimates from our baseline model imply that having at least two partners closely connected with the state adds between 4.4 and 6.4 percentage points to the rate of successful exits. Second, it confirms the importance of repeated relationships in China's guanxi networks. The estimated coefficient of network stability suggests that a one-standard-deviation increase in the index value is associated with a 4.9 percentage point increase in the exit rate. Third, a VC firm's position in its network is a significant factor for investment performance. Specifically, a one-standard-deviation increase in a VC firm's degree centrality is associated with a 6.1 percentage point increase in the exit rate. This result is particularly interesting when compared with the corresponding estimate for the US market by Hochberg et al. (2007) that a one-standard-deviation increase in degree centrality is associated with a 2.5 percentage point increase in the exit rate. This is despite the observation from the raw data that China's VC 
firms rely more on networks yet have lower exit rates than the US firms. The econometric analysis shows that, after controlling for other factors, VC networks have a larger impact on investment performance in China than in the US. Thus, our findings suggest that the predominance of guanxi in China magnifies the impact of networks on investment performance.

The remainder of the paper is organized as follows. Section II presents an overview of China's VC market, while Section III discusses the methodology of measuring VC networks. The baseline model and data description are presented in sections IV and V, respectively. Section VI discusses the estimation results from the baseline model, and section VII checks the robustness of our results by expanding the baseline model to include interaction terms and by examining a larger sample of VC firms. Concluding remarks are offered in section VIII.

\section{FEATURES OF CHINA's VC NETWORKS}

China's VC market has a short history, dating back to only 1999. Yet it has grown rapidly, fueled by domestic funds generated by fast economic growth and the inflow of foreign capital. The total investments in China’s venture capital market grew from US\$348 million in 1999 to US\$5387 million in 2010. In addition to foreign funds, China’s VC firms also come from a diverse range of domestic sources, consisting of the government, state-owned enterprises, and private firms.

Like their US counterparts, VC firms in China tend to syndicate their investments with other VC firms. According to the China Venture Capital Annual 2008, over 90 percent of venture capital investments in China were done through syndication. However, as has been noted by 
Walker and Pukthuanthong (2007), different cultural norms, governmental intervention and the degree of market maturity are important factors that set China's VC market apart from those in other countries. The same can be said about China's VC networks, two features of which are particularly worth noting.

First, China’s VC networks are based on guanxi or long term reciprocal personal relationships. This stems from China’s tradition as a "guanxi society," where personal relationships play an extremely important role in the social interactions among the Chinese people (Fei 1992). This feature of the guanxi society is widely observed in China's VC networks. Managers of VC firms usually prefer to confine their co-investment partners to those run by individuals with whom they have a trusting personal relationship. This reliance on trust among individuals rather than on formal institutions such as written contracts is partly a reflection of the fact that China does not yet have a strong, transparent and predictable legal system. Trusting relationships via one's guanxi network provides a VC manager with a means to navigate through the ambiguous and uncertain terrain of China’s economic landscape.

Second, cultivating guanxi with the agents and institutions of the Chinese state is particularly important for China's VC firms. Although China has made great strides towards the establishment of a market economy framework based on protection of property rights and the rule of law, the shadow of the old Soviet-style central planning still lurks in the background and the heavy hand of government interventions is still being felt in many areas of the economy (Liu et al. 2006). To navigate around the barriers created by the government interventions and to gain access to important decision-makers in the government, it is often essential for a business to 
cultivate guanxi with the agents and institutions of the state. This implies that the performance of a VC firm may depend on how well it is connected with the state. For example, stringent and lengthy regulatory reviews of applications for public listing on China's stock markets have led to a long waiting list of applicants, with the result that those companies that have strong (direct or indirect) ties with the government are more likely to be approved. This suggests that a VC firm that has good connections with the state should have a better track record of bringing its portfolio companies to successful IPOs. Furthermore, a VC firm well connected with the state is also in a better position to assist a portfolio company in obtaining the necessary regulatory approval for entry into markets and securing more business opportunities. For these reasons, we expect a positive association between a VC firm's investment performance and its connections with the Chinese state.

\section{MEASUREMENT OF VC NETWORKS}

To investigate the performance consequences of VC networks, it is necessary to construct quantitative measures of VC networks. In this study, we quantify a VC firm's networks along two dimensions. First, we follow Hochberg et al. (2007) and measure a VC firm's position in its network based on the concept of centrality, i.e., how “central” a VC firm's network position is. Second, we gauge the stability and reliability of a VC firm's network using an index based on the number of repeated relationships it has in the network. Note that the measure of network stability is not present in the study of the US VC markets by Hochberg et al. (2007). We incorporate this measure into our empirical analysis to capture the importance of trust and 
long-term relationships that characterize China’s guanxi networks.

\section{a) Network Centrality}

Network centrality refers to the position of a VC firm in a network. The more central is a firm's network position, the more influential it is in the network. This can be seen in a graph where nodes and arrows are used to represent the relationship between VC firms (Wasserman and Faust 1997). Figure 1, for example, is the graph of a network formed by the 20 most active VC firms in China. In the graph, nodes represent VC firms and arrows represent syndicate ties between them. The direction of an arrow indicates whether the VC firm is the originator that invites other VC firms to join a syndicate or it is a receiver of such an invitation. The arrow points from the originator of the tie (the lead member of the syndicate) to the receiver of the tie (a nonlead member). A two-directional arrow indicates that both VC firms on the arrow have at some point in the time window led a syndicate in which the other was a nonlead member. The more VC firms with which a VC firm is connected, the greater is its influence in the VC network. In Figure 1, it appears that firm 12 is the most central in the sense that it is connected to the largest number of VC firms.

Various indices have been constructed to measure the centrality of an actor in a network. In this analysis, we use three indices based on the concept of degree centrality: (undirected) degree, indegree, and outdegree. Degree counts the number of ties a VC firm has, that is, the number of VC firms with which a VC firm has co-invested. Formally, let $p_{i j}=1$ if at least one syndication relationship exists between VC firms $i$ and $j$, and $p_{i j}=0$ if no such relationship 
exists between them. Then VC firm $i$ 's degree equals $\sum_{j} p_{i j}$. Note that this measure does not take into account the direction of a tie, as it does not distinguish between an originator and a receiver.

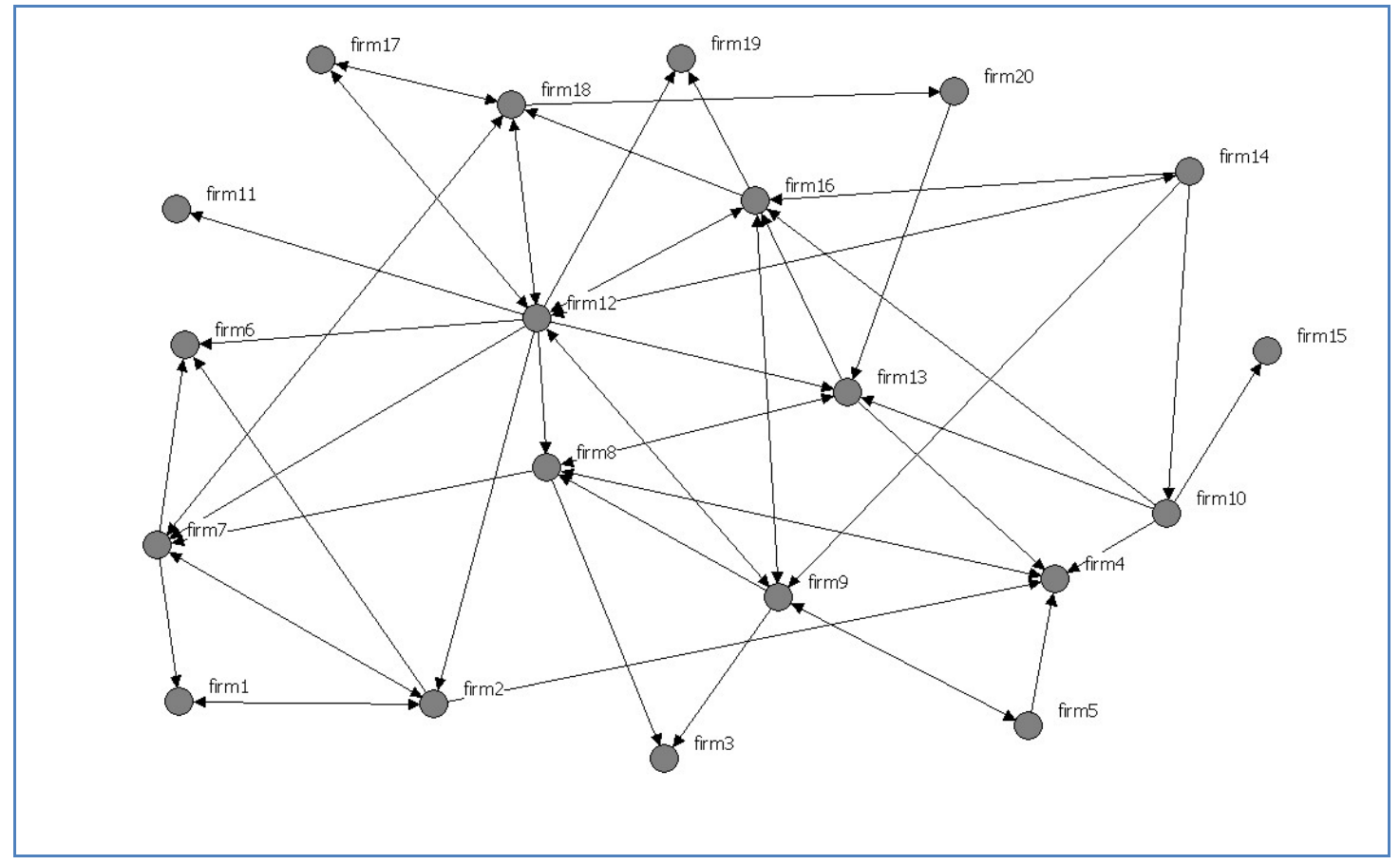

Figure 1 Networks of the 20 most active VC firms in China

Indegree and outdegree, on the other hand, make a distinction between an originator and a receiver. Indegree counts the number of other VC firms that have invited a particular VC firm to co-invest in portfolio companies, while outdegree numerates the number of other VC firms the VC firm has invited into its own syndicates. To be more precise, let $q_{j i}=1$ if at least one syndication relationship exists in which VC firm $j$ is the lead investor and VC firm $i$ is a syndicate member, and $q_{j i}=0$ otherwise. Then VC firm $i$ 's indegree equals $\sum_{j} q_{j i}$, and VC firm $j$ 's outdegree equals $\sum_{i} q_{j i}$. 
Given that the degree centrality indices as defined above depend on the size of a network, it is standard to normalize these indices by dividing it by the maximum possible degree, i.e., $n-1$ in an n-actor network. In our empirical analysis we use the normalized centrality measures.

\section{b) Network Stability}

Network stability takes into consideration the number of repeated relationships an actor has in a network. It has been used to measure the stability and reliability of an actor's relationships in a network (Oh and Jeon 2007). Formally, let $\lambda_{i j}=1$ if more than one syndication relationship exists between VC firms $i$ and $j$, and $\lambda_{i j}=0$ otherwise. Then VC firm $i$ 's stability index equals $\sum_{j} \lambda_{i j} / \sum_{j} p_{i j}$, recalling that $\sum_{j} p_{i j}$ measures the total number of syndication partners VC firm $i$ has. In other words, the stability index tells us the proportion of repeated relationships among all the syndication relationships a VC firm has had.

We use this measure of network stability to capture some of the features of China's guanxi networks, namely the importance of trust and long-term relationships. Mutual trust can be built through repeated episodes of cooperation. Moreover, repeated syndication relationships themselves are a manifestation of a long-term relationship. Accordingly, the fact that two VC firms continued to cooperate after their first syndication relationship is an indication of trust and possibly long-term relationship. ${ }^{2}$

\footnotetext{
${ }^{2}$ It should be pointed out that the essence of a long-term relationship is the repetition of cooperative interactions between two firms, rather than the temporal dimension of the relationship per se. In other words, it is the many repeated interactions that make a relationship long-term. Therefore, despite that the VC firms in our sample had only ten years of interaction at maximum, two firms can form a long-term relationship in the sense of many repeated episodes of cooperation during this period.
} 


\section{ECONOMETRIC MODEL}

Following Hochberg et al. (2007), we postulate that the investment performance of a VC firm is a function of its characteristics and its network. Specifically, we estimate the following as our baseline model: ${ }^{3}$

$$
P_{i}=\beta_{0}+\beta_{1} \ln \text { Size }_{i}+\beta_{2} \ln \text { Age }_{i}+\beta_{3}(\ln \text { Age })^{2}+\beta_{4} \text { Foreign }_{i}+\beta_{5} \text { State }_{i}+\beta_{6} \text { Network }_{i}+\varepsilon_{i},(1)
$$

where $P_{i}$ denotes the investment performance of VC firm $i, \beta_{j}(j=0,1, \ldots 6)$ are the coefficients to be estimated, and $\varepsilon_{i}$ is the random error term. The first three variables on the right hand side are firm characteristics, while the last two variables measure a firm’s network.

Specifically, the firm characteristics are its size, age, and whether it is foreign-owned. In (1), both size and age are expressed in natural logarithm. The size of a VC firm can affect its performance if there are economies of scale in the provision of value-added services to portfolio companies. The latter would arise if, for example, large VC firms are more likely to attract good-quality managers than small VC firms. In addition, the size of a VC firm could be a signal of its past efficiency of capital operations; it is easier for a VC firm with a reputation of efficient operations to raise additional funds in the market (Gompers and Lerner 1999, Nahata 2008).

The age of a VC firm is a proxy for its experience. We express model (1) as a quadratic function of $\ln$ Age to admit the possibility of a U-shaped relationship between investment performance and the age of a VC firm. Intuitively, a young VC firm has an initial learning period during which it may be more prone to mistakes and consequently its performance may not

${ }^{3}$ In Section VII, we expand this model to include interaction terms between size and other variables. 
necessarily increase with age. We conjecture that this may particularly be the case for China's VC market because its short history means that at the beginning of our sample period, most VC firms were inexperienced and they did not have the benefit of learning from the past experience of established VC firms. In the longer term, however, we expect that older VC firms have gained more experience and become better at selecting promising portfolio companies to invest in and providing the latter with better services, both of which should lead to superior investment performance. In other words, we expect a positive relationship between age and investment performance in the longer term.

We include a dummy for foreign ownership in our model to account for the fact that China's VC markets had a short history, and the domestic VC firms are much less experienced than their foreign counterparts that have been in operation for many years (albeit in other countries). Foreign-owned VC firms are able to draw from their many years of experience gained from operating in other countries and rely on their international reputation to attract promising portfolio companies. On the other hand, domestic VC firms may have better knowledge about and hence may be more adept at navigating through the idiosyncrasy of China's markets and institutions. Both suggest that the investment performance of domestic and foreign VC firms may differ, ceteris paribus. But ex ante it is not clear whether foreign ownership has a positive or negative impact on performance.

The fourth independent variable, State, is a dummy variable that captures a VC firm's connections with the Chinese state. It takes on the value of 1 if a VC firm had two or more partners that are state-owned enterprises or are closely affiliated with the state, and 0 otherwise. 
We include this dummy in the econometric model to take into account the fact that the Chinese state plays an active and powerful role in many facets of the Chinese economy, including the VC market. For reasons discussed in section II, we hypothesize that connections with the Chinese state would improve the investment performance of a VC firm.

Finally, the fifth independent variable, Network, represents the centrality and network stability of a VC firm. As has been discussed in section III, we use four measures of networks: degree, indegree, outdegree, and stability.

This study faces the same data challenge as previous empirical works on VC networks that information on VC firm's rate of return is not publicly available. Following Hochberg et al. (2007 and 2010) and Kaplan and Schoar (2005), we use the exit rate as a proxy for the investment performance of VC firms. The exit rate here refers to the fraction of portfolio companies that are successfully exited via an IPO or a sale to another party. The exit rate is a reasonable indicator of a VC firm's investment performance because only when an investment is successful can a VC firm exit via an IPO or a sale; otherwise, the investment can only be liquidated.

\section{DATA DESCRIPTION}

Data used in our econometric analysis were obtained from Zdatabase (http://www.zdbchina.com/Reg.aspx), which is the only online database on China's VC industry. ${ }^{4}$ Since VC as an industry in China dates back to only $1999,{ }^{5}$ we use the data from that

\footnotetext{
${ }^{4}$ Zdatabase was formerly named Zero2ipo. Another data source of China's VC industry is CVSource, but its coverage is not as comprehensive as Zdatabase.
} 
point onward to compute the variables used in econometric estimation. Taking into consideration that it takes time for a VC firm to select the portfolio companies to invest in and then to supervise and nurture them to the point that allows a successful exit, ${ }^{6}$ we include in our analysis those investments that were made by VC firms from 1999 to 2005 - four years prior to the year when the latest data on investment performance is available (i.e., 2009). With the exit rates of these VC firms calculated over the 10-year period from 1999 to 2009, the youngest VC firms included in our econometric study have at least 4 years of operation. Among the independent variables, the values of Network and State are calculated using the data on the VC firms' syndication behavior between 1999 and 2005. The values of Size and Foreign are determined, respectively, by the amount of registered capital and the ownership at the time when the VC firm was first registered in China. ${ }^{7}$ Finally, Age is a VC firm's years of operation in China until 2009.

The econometric analysis is conducted for a sample of 100 most active VC firms during the period 1999 - 2009. We have chosen this sample instead of the entire population of all VC firms to remove the effects of outliers, specifically those of small VC firms that invested in only a small number of projects. Because China's VC industry is young and has been rapidly expanding, the distribution of investment activities across China's VC firms is highly skewed, with the 100 most active firms accounting for the majority of the investments. To be more

\footnotetext{
5 This is the year when the government in China permitted institutional investors to invest in venture capital funds. A small number of VC firms were established prior to 1999.

${ }^{6}$ The typical cycle of a closed-end VC fund is 10 years, with the first six years or so devoted to selecting and nurturing portfolio companies. Exits typically occur in the latter half of the cycle.

${ }^{7}$ It is reasonable to measure these two variables based on the time of registration because most of the VC firms in China are structured as closed-end funds.
} 
specific, there were 319 VC firms registered in China in 2005, and these VC firms invested in 4188 projects between 1999 and 2009. Among those, 2385 projects, or 57.0 percent, belonged to the 100 most active VC firms. Put it differently, each of these 100 VC firms invested in an average of 23.9 projects, which is approximately three times the average of the remaining 219 VC firms. ${ }^{8}$ The distribution of VC firms is even more skewed when measured in terms of the value of investments. During this period, the 100 most active VC firms invested \$3328 million, accounting for 70.8 percent of the total investments made by the 319 firms. By focusing on the 100 most active VC firms in China, we remove the potential effects caused by the "long-tail".

Table I Descriptive Statistics of the 100 VC firms

\begin{tabular}{|c|c|c|c|c|c|}
\hline Variable & Definition & Min & Max & Mean & Std. Dev. \\
\hline Network & Degree & 0.0520 & 0.3960 & 0.1608 & 0.0607 \\
\hline Network & Outdegree & 0.0000 & 0.2400 & 0.0856 & 0.0536 \\
\hline Network & Indegree & 0.0200 & 0.3520 & 0.0640 & 0.0608 \\
\hline Network & Stability & 0.0500 & 0.5000 & 0.1898 & 0.0888 \\
\hline Size & $\begin{array}{c}\text { Firm Size } \\
\text { (in US\$ million) }\end{array}$ & 10.0000 & 347.0000 & 33.2800 & 52.164 \\
\hline Age & Age (year) & 4.0000 & 25.0000 & 8.6880 & 3.8633 \\
\hline Foreign & Foreign Ownership & 0.0000 & 1.0000 & 0.4900 & 0.5025 \\
\hline State & $\begin{array}{l}\text { Connections with } \\
\text { the State }\end{array}$ & 0.0000 & 1.0000 & 0.5400 & 0.5009 \\
\hline$P$ & Exit Rate & 0.0600 & 1.0000 & 0.2595 & 0.1734 \\
\hline
\end{tabular}

Source: Authors' own calculations using data from Zdatabase.

Descriptive statistics of these 100 VC firms are presented in Table I. The average size of these firms is $\$ 33.28$ million of committed capital. The average age of the VC firms in our

\footnotetext{
${ }^{8}$ On average, each of the remaining 219 VC firms invested in 8.2 projects during the 10 -year period.
} 
sample is 8.7 years, reflecting the short history of China’s VC industry. Slightly less than half (49 percent) of VC firms are foreign-owned. More than half of the sample firms (54 percent) are well connected to the state, in the sense that they have had two or more partners that are state-owned enterprises or are closely affiliated with the state.

Turning to the measures of VC networks, the average degree centrality of the sample firms is 0.161, implying that an average VC firm in the sample has close to 16 ties among the 99 possible relationships. While the degree centrality has a fairly wide range between 0.05 and 0.40 , its standard deviation is small at 0.0607. The average outdegree and indegree are 0.086 and 0.064 , respectively. The average network stability is 0.19 , indicating that on average a VC firm has developed repeated relationships with close to 20 percent of its partners.

The average exit rate of the sample VC firms is 0.2595 . In other words, the average firm in the sample successfully exited 26 percent of the portfolio companies they invested in. Note the wide variations in the exit rate, with a standard deviation of 0.17 and a range of between 0.06 and 1.00 .

Table II VC Networks and Investment Performance: China vs. United States

\begin{tabular}{|c|c|c|}
\hline & China & United States \\
\hline Degree & 0.1608 & 0.04237 \\
\hline Outdegree & 0.0856 & 0.01203 \\
\hline Indegree & 0.0640 & 0.01003 \\
\hline Exit Rate & $25.95 \%$ & $34.2 \%$ \\
\hline
\end{tabular}

Source: Values for China were from the authors' own calculations, and those for the United States were from Table I in Hochberg et al. (2007).

It is interesting to compare the measures of VC networks and investment performance in 
China with those of the United States. As can be seen from Table II, the 100 most active VC firms in China rely on networks to a greater extent than the average VC firm in the United States, in terms of the sample means of all three centrality measures. This is consistent with the observation that guanxi plays a very important role in China. On the other hand, the average exit rate of China's VC firms is significantly lower than that of the American firms. On the surface this seems to suggest that the heavier reliance on networks by China's VC firms does not really enhance their investment performance. However, such an observation could be misleading as it does not control for other factors that may influence the performance of VC firms. To properly isolate the effects of VC networks in China, an econometric analysis is needed. This we turn to in the next section.

\section{ESTIMATION RESULTS}

The econometric model (1) has been estimated using White's heteroscedasticity-consistent estimator (White 1980). The latter has been used because the White test indicates the presence of heteroscedasticity. Four separate specifications are estimated, using the four measures of VC networks: degree, indegree, outdegree, and network stability. Following Hochberg et al. (2007), we include each of these network measures one at a time to avoid problems caused by multicollinearity. ${ }^{9} \quad$ Our econometric results are summarized in Table III.

These results show that, as expected, the size of VC firms has a positive and statistically significant effect on investment performance, and this is true for all four model specifications.

\footnotetext{
${ }^{9}$ On the other hand, the VIF (Variance Inflation Factor) test indicates that multicollinearity is not a problem among the remaining variables.
} 
The experience of VC firms, on the other hand, has a U-shaped relationship with investment

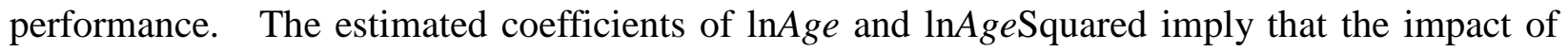
age on investment performance is negative in the first two years of a VC firm, but it becomes positive starting from the third year.

Table III. Estimation Results from the Baseline Model

\begin{tabular}{|c|c|c|c|c|}
\hline $\begin{array}{l}\text { Independent } \\
\text { Variable }\end{array}$ & (1) & (2) & (3) & (4) \\
\hline $\ln$ Size & $\begin{array}{c}0.053^{* * *} \\
(3.219)\end{array}$ & $\begin{array}{c}0.058^{* * *} \\
(3.748)\end{array}$ & $\begin{array}{c}0.081^{* * *} \\
(4.171)\end{array}$ & $\begin{array}{c}0.068 * * * \\
(2.981)\end{array}$ \\
\hline $\ln A g e$ & $\begin{array}{c}-1.297 * * * \\
(-3.991)\end{array}$ & $\begin{array}{c}-2.021^{* * *} \\
(-7.013)\end{array}$ & $\begin{array}{c}-1.634^{* * *} \\
(-5.238)\end{array}$ & $\begin{array}{c}-1.504^{* * *} \\
(-5.868)\end{array}$ \\
\hline In Age Squared & $\begin{array}{c}0.900^{* * *} \\
(4.616)\end{array}$ & $\begin{array}{c}1.299 * * * \\
(6.995)\end{array}$ & $\begin{array}{c}1.162 * * * \\
(5.987) \\
\end{array}$ & $\begin{array}{c}1.014^{* * *} \\
(6.226) \\
\end{array}$ \\
\hline Foreign & $\begin{array}{c}-0.022 * * \\
(-2.016) \\
\end{array}$ & $\begin{array}{c}-0.017^{* * *} \\
(-1.750) \\
\end{array}$ & $\begin{array}{l}-0.023^{*} \\
(-1.880) \\
\end{array}$ & $\begin{array}{c}-0.013 \\
(-1.140) \\
\end{array}$ \\
\hline State & $\begin{array}{c}0.056^{* * * *} \\
(3.924) \\
\end{array}$ & $\begin{array}{c}0.044^{* * *} \\
(3.151)\end{array}$ & $\begin{array}{c}0.058^{* * * *} \\
(3.409) \\
\end{array}$ & $\begin{array}{c}0.064 * * * \\
(4.084) \\
\end{array}$ \\
\hline Degree & $\begin{array}{c}0.999 * * * \\
(4.428) \\
\end{array}$ & & & \\
\hline Outdegree & & $\begin{array}{c}-1.093^{* * *} \\
(-5.771) \\
\end{array}$ & & \\
\hline Indegree & & & $\begin{array}{l}0.360^{* *} \\
(1.362) \\
\end{array}$ & \\
\hline Stability & & & & $\begin{array}{c}0.550^{* * *} \\
(3.433) \\
\end{array}$ \\
\hline Constant & $\begin{array}{c}0.533^{* * * *} \\
(3.540) \\
\end{array}$ & $\begin{array}{c}1.110^{* * *} \\
(9.877) \\
\end{array}$ & $\begin{array}{c}0.780^{* * *} \\
(6.121) \\
\end{array}$ & $\begin{array}{c}0.682 * * * \\
(6.707) \\
\end{array}$ \\
\hline $\mathrm{N}$ & 100 & 100 & 100 & 100 \\
\hline $\mathrm{R}^{2}$ & 0.905 & 0.905 & 0.876 & 0.897 \\
\hline
\end{tabular}

Note: $* * *, * *$, and $*$ denote statistical significance at the $1 \%, 5 \%$, and $10 \%$ level, respectively.

The impact of foreign ownership on investment performance is generally negative, with the estimated coefficient significantly negative in three of the four specifications. In other words, 
foreign-owned VC firms do not perform as well as their domestic counterparts, ceteris paribus. This suggests that familiarity with local culture and customs and understanding of the idiosyncrasies of China's markets and institutions are important for the success of a VC firm in China.

The empirical study presents strong evidence that China's guanxi networks have a significant impact on investment performance. First, it shows that close connections with the state contribute to a VC firm's investment performance. In all four specifications the estimated coefficient of State is statistically significant at 1 percent level, implying that having two or more partners closely tied with the state adds between 4.4 to 6.4 percentage points to the exit rate. Second, it confirms the importance of repeated relationships in China's guanxi networks. The estimated coefficient of Stability, significant at 1 percent level, implies that a one-standard-deviation increase in Stability is associated with a 4.9 percentage point increase in the exit rate. Third, a VC firm's position in its network is a significant factor for investment performance. Specifically, a one-standard-deviation increase in a VC firm's degree centrality is associated with a 6.1 percentage point increase in the exit rate. This result is particularly interesting when compared with the corresponding estimate for the US market by Hochberg et al. (2007) that a one-standard-deviation increase in degree centrality is associated with a 2.5 percentage point increase in the exit rate. Despite the earlier observation from Table II that China's VC firms rely more on networks yet have lower exit rates than the US firms, the econometric analysis shows that, after controlling for other factors, VC networks have a larger impact on investment performance in China than in the US. This indicates that networks are 
more important for investment performance in China than in the US. ${ }^{10}$

Note, however, that the positive impact of degree centrality in China's VC networks manifests itself through indegree rather than outdegree. The econometric analysis shows that the estimated coefficient is positive for Indegree but negative for Outdegree. This implies that while being a frequent receiver of invitations to co-invest improves a VC firm's performance, being a frequent originator of such invitations does not. The latter, however, does not necessarily mean that inviting other VC firms to co-invest brings no benefit to the originator. A VC firm that invites others to its syndicates today can expect, through reciprocity, to receive more invitations to co-invest in the future. But this inter-temporal benefit of being an originator is embodied in the positive coefficient of Indegree. Moreover, the negative coefficient of Outdegree is obtained after controlling for, among other things, a VC firm's connections with the state. In other words, the benefits from inviting partners closely affiliated with the state are already captured in the coefficient of State. Therefore, we should interpret the negative sign of Outdegree to mean that being a frequent originator brings no immediate benefit, after controlling for partnerships with agents and institutions of the state.

${ }^{10}$ In section VII, we show that the estimation results from a larger sample of 150 most active VC firms in China lend further support to this conclusion. More generally, we believe that this conclusion is robust to the inclusion of the remaining 169 firms in the analysis. To overturn our conclusion, the impact of degree centrality on investment performance for these 169 firms would have to be substantially smaller than that for the 150 most active firms. This would imply that the former have substantially higher degrees of centrality (relative to their exit rates) than the latter, which is unlikely considering that the former are much less active actors in the VC market than the latter. 


\section{ROBUSTNESS CHECKS}

To check the robustness of our findings, we conduct two additional sets of estimations. In the first set, we add interaction terms to our baseline model (1). In the second set, we estimate the expanded model using a larger sample of $150 \mathrm{VC}$ firms. In both instances, we use White's heteroscedasticity-consistent estimator to correct heteroscedasticity.

As the first robustness test, we expand the baseline model (1) by including interaction terms between the network variables and Size. Specifically, we estimate the following expanded model:

$$
\begin{aligned}
P_{i}= & \beta_{0}+\beta_{1} \ln \text { Size }_{i}+\beta_{2} \ln \text { Age }_{i}+\beta_{3}\left(\ln \text { Age }_{i}\right)^{2}+\beta_{4} \text { Foreign }_{i}+\beta_{5} \text { State }_{i}+\beta_{6} \text { Network }_{i} \\
& \beta_{7} \ln \text { Size }_{i} \times \ln \text { Age }_{i}+\beta_{8} \ln \text { Size }_{i} \times \text { Network }_{i}+\varepsilon_{i}
\end{aligned}
$$

In Table IV, we present the estimation results from the expanded model. It shows that the inclusion of these interaction terms amplifies the marginal effect of networks on investment performance. In particular, a one-standard-deviation increase in a VC firm's degree centrality is now associated with an 8.9 percentage point increase in the exit rate, in comparison with the 6.1 percentage point from the baseline model. A one-standard-deviation increase in Stability is associated with an 8.7 percentage point increase in the exit rate, substantially higher than the 4.9 percentage point from the baseline model. Moreover, the estimated coefficients of the interaction terms indicate that a larger fund size reinforces the effect of networks on investment performance. The remaining estimated coefficients are also qualitatively the same as those from the baseline model (1). 
Table IV Estimation Results with Interaction Terms

\begin{tabular}{|c|c|c|c|c|}
\hline $\begin{array}{l}\text { Independent } \\
\text { Variable }\end{array}$ & (1) & (2) & (3) & (4) \\
\hline ln Size & $\begin{array}{c}0.127 * * * \\
(3.194)\end{array}$ & $\begin{array}{c}0.292 * * * \\
(3.007)\end{array}$ & $\begin{array}{c}0.174 * * * \\
(3.226)\end{array}$ & $\begin{array}{c}0.135 * * \\
(2.203)\end{array}$ \\
\hline $\ln$ Age & $\begin{array}{c}-1.289 * * * \\
(-4.791)\end{array}$ & $\begin{array}{c}-1.864 * * * \\
(-13.273)\end{array}$ & $\begin{array}{c}-1.512 * * * \\
(-5.632)\end{array}$ & $\begin{array}{c}-1.429 * * * \\
(-5.435)\end{array}$ \\
\hline In Age Squared & $\begin{array}{c}0.812 * * * \\
(4.722)\end{array}$ & $\begin{array}{c}1.107 * * * \\
(9.675)\end{array}$ & $\begin{array}{c}1.032 * * * \\
(6.021)\end{array}$ & $\begin{array}{c}0.907 * * * \\
(5.932)\end{array}$ \\
\hline Foreign & $\begin{array}{l}-0.023 * * \\
(-2.040)\end{array}$ & $\begin{array}{c}-0.006 \\
(-0.758)\end{array}$ & $\begin{array}{l}-0.025^{*} \\
(-1.986)\end{array}$ & $\begin{array}{c}-0.015 \\
(-1.350)\end{array}$ \\
\hline State & $\begin{array}{c}0.053 * * * \\
(3.851)\end{array}$ & $\begin{array}{c}0.038 * * * \\
(2.967)\end{array}$ & $\begin{array}{c}0.057 * * * \\
(3.348)\end{array}$ & $\begin{array}{c}0.062 * * * \\
(4.117)\end{array}$ \\
\hline Degree & $\begin{array}{c}1.470 * * * \\
(4.826)\end{array}$ & & & \\
\hline Outdegree & & $\begin{array}{c}-2.658 * * * \\
(-6.942) \\
\end{array}$ & & \\
\hline Indegree & & & $\begin{array}{c}0.834^{* *} \\
(2.163)\end{array}$ & \\
\hline Stability & & & & $\begin{array}{c}0.980 * * * \\
(6.396)\end{array}$ \\
\hline $\ln$ Size $\mathrm{X} \ln A g e$ & $\begin{array}{c}-0.218 * * * \\
(-2.884)\end{array}$ & $\begin{array}{c}-0.146 \\
(-1.602)\end{array}$ & $\begin{array}{l}-0.158 * \\
(-1.969)\end{array}$ & $\begin{array}{c}-0.220 * * \\
(-2.017)\end{array}$ \\
\hline InSize X Degree & $\begin{array}{c}0.761 * * * \\
(2.983)\end{array}$ & & & \\
\hline lnSize X Outdegree & & $\begin{array}{c}-1.285 * * * \\
(-4.639) \\
\end{array}$ & & \\
\hline lnSize X Indegree & & & $\begin{array}{c}0.964 * * \\
(2.043)\end{array}$ & \\
\hline lnSize X Stability & & & & $\begin{array}{c}0.651 * * * \\
(2.971)\end{array}$ \\
\hline Constant & $\begin{array}{c}0.520 * * * \\
(4.024)\end{array}$ & $\begin{array}{l}1.240 * * * \\
(23.782)\end{array}$ & $\begin{array}{c}0.748 * * * \\
(6.417)\end{array}$ & $\begin{array}{c}0.611^{* * *} \\
(5.134)\end{array}$ \\
\hline $\mathrm{N}$ & 100 & 100 & 100 & 100 \\
\hline $\mathrm{R}^{2}$ & 0.914 & 0.930 & 0.885 & 0.910 \\
\hline
\end{tabular}

Note: $* * *, * *$, and * denote statistical significance at the $1 \%, 5 \%$, and $10 \%$ level, respectively.

To test whether our conclusions are sensitive to the sample size, we estimate model (2) using 
the data from the 150 most active VC firms. The descriptive statistics of these 150 firms are presented in Table V. A comparison of Table V with Table I reveals that the inclusion of 50 additional firms reduces the mean of every variable. This is not surprising since these additional firms are less active and, accordingly, are generally smaller in size.

Table V Descriptive Statistics of the 150 VC firms

\begin{tabular}{ccccccc}
\hline Variable & Definition & No. & Min & Max & Mean & Std. Dev. \\
\hline Network & Degree & 150 & 0.0201 & 0.3154 & 0.1141 & 0.1175 \\
Network & Outdegree & 150 & 0.0000 & 0.1678 & 0.0628 & 0.1026 \\
$\begin{array}{c}\text { Network } \\
\text { Network } \\
\text { Size }\end{array}$ & Indegree & 150 & 0.0134 & 0.2148 & 0.0604 & 0.0723 \\
& Stability & 150 & 0.0000 & 0.1946 & 0.0671 & 0.1182 \\
& Fund size & & & & & \\
Age & (in US\$ million ) & 150 & 4.6153 & 347.0000 & 23.3243 & 52.157 \\
Foreign & Age (year) & 150 & 4.0000 & 25.0000 & 6.6667 & 7.7943 \\
& Foreign & 150 & 0.0000 & 1.0000 & 0.3133 & 0.6213 \\
State & Ownership & & & & & \\
& Connections with & 150 & 0.0000 & 1.0000 & 0.3667 & 0.6011 \\
$P$ & the State & & & & & \\
\hline
\end{tabular}

Source: Authors' own calculations using data from Zdatabase.

The estimation results from the $150 \mathrm{VC}$ firms are presented in Table VI. They are qualitatively the same as those from the 100 firms in Table IV. In particular, State, Degree and Stability continue to have significantly positive effects on investment performance. Quantitatively, the estimated coefficients are smaller (in absolute value) in Table VI than those in Table IV in most instances. This is not surprising considering that the means of all variables are smaller for the 150 firms. 
Table VI Estimation Results of the 150 VC Firms

\begin{tabular}{|c|c|c|c|c|}
\hline $\begin{array}{l}\text { Independent } \\
\text { Variable }\end{array}$ & (1) & (2) & (3) & (4) \\
\hline ln Size & $\begin{array}{l}0.115 * * \\
(2.174)\end{array}$ & $\begin{array}{c}0.156^{* * *} \\
(3.216)\end{array}$ & $\begin{array}{c}0.246 * * * \\
(4.348) \\
\end{array}$ & $\begin{array}{c}0.128 * * \\
(2.157)\end{array}$ \\
\hline $\ln$ Age & $\begin{array}{c}-1.185 * * \\
(-2.011) \\
\end{array}$ & $\begin{array}{c}-1.064 * * * \\
(-6.383) \\
\end{array}$ & $\begin{array}{l}-1.245^{* *} \\
(-5.934)\end{array}$ & $\begin{array}{c}-1.134 * * * \\
(-5.838)\end{array}$ \\
\hline ln Age Squared & $\begin{array}{c}0.753 * * \\
(2.112)\end{array}$ & $\begin{array}{c}1.124 * * * \\
(6.678)\end{array}$ & $\begin{array}{l}1.005^{* *} \\
(2.079)\end{array}$ & $\begin{array}{c}0.875 * * * \\
(4.531)\end{array}$ \\
\hline Foreign & $\begin{array}{l}-0.012^{*} \\
(-1.840)\end{array}$ & $\begin{array}{c}-0.009 \\
(-0.368)\end{array}$ & $\begin{array}{l}-0.017^{*} \\
(-1.976) \\
\end{array}$ & $\begin{array}{c}-0.014 \\
(-1.451)\end{array}$ \\
\hline State & $\begin{array}{c}0.049 * * * \\
(4.357)\end{array}$ & $\begin{array}{c}0.021 * * * \\
(3.863)\end{array}$ & $\begin{array}{c}0.044 * * * \\
(3.446)\end{array}$ & $\begin{array}{c}0.081^{* * *} \\
(5.983)\end{array}$ \\
\hline Degree & $\begin{array}{l}1.128 * \\
(1.899)\end{array}$ & & & \\
\hline Outdegree & & $\begin{array}{l}-1.967 * * \\
(-2.082)\end{array}$ & & \\
\hline Indegree & & & $\begin{array}{c}0.739 * * \\
(2.053)\end{array}$ & \\
\hline Stability & & & & $\begin{array}{l}0.101^{*} \\
(1.896)\end{array}$ \\
\hline $\ln$ Size $\mathrm{X} \ln A g e$ & $\begin{array}{l}-0.223^{*} \\
(-1.781) \\
\end{array}$ & $\begin{array}{c}-0.121 \\
(-1.592) \\
\end{array}$ & $\begin{array}{l}-0.145^{*} \\
(-1.987) \\
\end{array}$ & $\begin{array}{c}-0.193 * * \\
(-2.006)\end{array}$ \\
\hline lnSize X Degree & $\begin{array}{l}0.479 * \\
(1.903)\end{array}$ & & & \\
\hline lnSize X Outdegree & & $\begin{array}{c}-1.079 * * \\
(-2.109)\end{array}$ & & \\
\hline lnSize X Indegree & & & $\begin{array}{l}1.035 * * \\
(2.013)\end{array}$ & \\
\hline lnSize X Stability & & & & $\begin{array}{l}0.751 * \\
(1.871)\end{array}$ \\
\hline Constant & $\begin{array}{l}0.410 * * \\
(2.021)\end{array}$ & $\begin{array}{l}1.135 * * * \\
(15.682)\end{array}$ & $\begin{array}{c}0.457 * * \\
(2.017)\end{array}$ & $\begin{array}{c}0.513 * * \\
(2.101)\end{array}$ \\
\hline$\overline{\mathrm{N}}$ & 150 & 150 & 150 & 150 \\
\hline $\mathrm{R}^{2}$ & 0.765 & 0.667 & 0.689 & 0.672 \\
\hline
\end{tabular}

Note: $* * *, * *$, and $*$ denote statistical significance at the $1 \%, 5 \%$, and $10 \%$ level, respectively.

Finally, it is worth noting that our estimation results from the 150 firms lend further support to our earlier conclusion regarding the comparison of the VC networks in China and the US. On 
the one hand, a comparison of Table II and Table V shows that VC firms in China rely more on networks yet have a lower exit rate than those in the United States. On the other hand, the estimated coefficient of Degree in Table VI implies that, after controlling for other factors, a one-standard-deviation increase in a VC firm's degree centrality is associated with 13.3 percentage point increase in the exit rate, substantially higher than the 2.5 percentage point for the US firms estimated by Hochberg et al. (2007).

\section{CONCLUDING REMARKS}

To investigate the relationship between VC networks and investment performance in China, we have estimated an econometric model that incorporates salient features of China's VC networks. Specifically, we have added an index of network stability to represent the role of guanxi that places great value on long-term repeated relationships, and included a dummy variable to investigate the performance consequences of VC firms' connections with the Chinese state. Following the seminal work of Hochberg et al. (2007), we have used indices of centrality to measure the relative importance of each actor in VC networks and the exit rate as a proxy for investment performance.

Our econometric analysis shows that China's guanxi networks have a significant impact on the investment performance of VC firms. Specifically, both network stability and close connections with the state contribute to the investment performance of VC firms. Consistent with the findings about the American VC market by Hochberg et al. (2007), a VC firm's position in its network is a significant factor for investment performance in China as well. Interestingly, 
the magnitude of this effect is much larger in China than in the US. This is despite the observation from the raw data that China's VC firms rely more on networks yet have lower exit rates than the US firms. The econometric analysis shows that, after controlling for other factors, VC networks have a larger impact on investment performance in China than in the US. This indicates that networks are more important for investment performance in China than in the US. In addition, our analysis implies that familiarity with local culture and customs and understanding of the idiosyncrasies of China's markets and institutions are important for the success of a VC firm in China.

Finally, we should point out two caveats about this study. First, our econometric model does not address the possible endogeneity of the network variables. For example, it is possible that a higher exit rate enables a VC firm to improve its network position. While we have not been able to deal with the endogeneity problem directly because of the data constraint imposed by the short history of China's VC market, we believe that our network variables are not very susceptible to this problem. This is because these network variables were computed using the data from the first six years of China's VC market. Given that it typically takes that many years for a VC firm to select the portfolio companies to invest in and then to nurture them to the point that allows a successful exit, most VC firms did not yet have a track record of successful exits during these early years of China's VC market. Accordingly, their network positions should not have been affected by their (non-existent) track record. Therefore, it is unlikely that our estimation has been influenced significantly by the endogeneity problem.

Second, this analysis does not take into consideration the evolving nature of guanxi and 
networks. In following the approach of Hochberg et al. (2007), we have adopted an essentially static framework. The static approach was necessary for this study because our sample period is not long enough due to the short history of China's VC market. We reckon that a dynamic analysis of guanxi networks in China's VC market is a fruitful avenue for research in the future when more years of data become available. 


\section{REFERENCES}

Brander, James A., Raphael Amit, and Werner Antweiler, 2002, Venture capital syndication: Improved venture selection vs. the value-added hypothesis, Journal of Economics \& Management Strategy, 11: 423-452.

Bygrave, William D., 1988, The structure of the investment networks of venture capital firms, Journal of Business Venturing 3, 137-158.

Dimov, Dimo and Hana Milanov, 2010, The interplay of need and opportunity in venture capital investment syndication, Journal of Business Venturing, 25: 331-348.

Fei, Xiaotong, 1992, From the Soil: The Foundations of Chinese Society, Berkley: University of California Press

Fund, B.R., T. G. Pollock, T. Baker and A. Wowak, 2008, Who's the new kid? The process of developing centrality in venture capitalist deal networks, Advances in Strategic Management, 25:563-593.

Gompers, Paul and Josh Lerner, 1999, An analysis of compensation in the U.S. venture capital partnership, Journal of Financial Economics, 51: 3-44.

Hochberg, Yael V., Alexander Ljungqvist and Yang Lu, 2007, Whom you know matters: Venture capital networks and investment performance, Journal of Finance, 62:252-301.

Hochberg, Yael, Alexander Ljungqvist and Yang Lu , 2010, Networking as a barrier to entry and the competitive supply of venture capital, Journal of Finance, 2010, 65:829-859.

Hopp, Christian and Finn Rieder, 2011, What drives venture capital syndication? Applied Economics , 43: 3089-3102.

Kaplan, Steven N and Antoinette Schoar, 2005, Private equity returns: Persistence and capital flows, Journal of Finance, 60:1791-1823.

Kaplan, Steven N., and Per Stromberg, 2004, Characteristics, contracts and actions: Evidence from venture capital analyses, Journal of Finance, 59: 2177- 2210.

Lerner, Josh, 1994, The syndication of venture capital investments, Financial Management, 23:16-27.

Lockett, Andy, and Mike Wright, 2001, The syndication of venture capital investments, Omega, 29: 375-390.

Liu, M., J.A. Zhang and B. Hu, 2006, Domestic VCs versus foreign VCs: A close look at the Chinese venture capital industry, International Journal of Technology Management, 34:161-184.

McNally, Christopher A., 2011, China’s changing guanxi capitalism: Private entrepreneurs between Leninist control and relentless accumulation, Business and Politics, 13(2): Article 5. 
Nahata, Rajarishi, 2008, Venture capital reputation and investment performance, Journal of Financial Economics, 90:127-151.

Oh, Wonseok, and Sangyong Jeon, 2007, Membership herding and network stability in the open source community: The Ising perspective, Management Science, 53:1086-1101.

Park, S. H., and Luo, Y. 2001, Guanxi and organizational dynamics: Organizational networking in Chinese firms, Strategic Management Journal, 22: 455-477.

Sahlman, William A, 1990, The structure and governance of venture capital organizations, Journal of Financial Economics, 27:473-421.

Sorenson, Olav, and Toby. E. Stuart, 2001, Syndication networks and the spatial distribution of venture capital investments, American Journal of Sociology, 106: 1546-1588.

Sorenson, Olav, and Toby E. Stuart, 2008, Bringing the context back in: Settings and the search for syndicate partners in venture capital investment networks, Administrative Science Quarterly, 53: 266-294.

Stuart, Toby E., and O. Sorenson, 2007, Strategic networks and entrepreneurial ventures, Strategic Entrepreneurship Journal, 1: 211-227.

Walker, Thomas John, and Kuntara Pukthuanthong, 2007, Venture capital in China: A culture shock for western investors, Management Decision, 45:708-731.

Wasserman, Stanley, and Katherine Faust, 1997, Social Network Analysis: Methods and Applications, New York: Cambridge University Press.

White, Halbert, 1980, A heteroskedasticity-consistent covariance matrix estimator and a direct test for heteroskedasticity, Econometrica, 48 (4): 817-838.

Wright, M., and A Lockett, 2003, The structure and management of alliances: Syndication in the venture capital industry, Journal of Management Studies, 40: 2073-2102. 